\title{
A revelação divina hoje: uma percepção do agir de Deus na história a partir de Andrés Torres Queiruga
}

\author{
Orientador: Mario de França Miranda \\ Doutorando: José Aguiar Nobre \\ Área de Concentração: Teologia Sistemático-Pastoral \\ Linha de Pesquisa: Religião e Modernidade \\ Projeto de Pesquisa: Fé e Cultura Pluri-Religiosa
}

A revelação divina hoje caracteriza-se por um trabalho de pesquisa sobre a concepção da revelação de Deus na história. Enfatiza um repensar contínuo da percepção de Deus como condição para a realização humana, à luz do pensamento de Andrés Torres Queiruga. Circunscreve-se a uma preocupação com a fé diante da sensibilidade do homem hodierno, com atenção à situação cultural, nascida a partir da modernidade. Metodologicamente, buscamos: compreender a concepção tradicional de revelação; discorrer sobre a teologia da revelação de Torres Queiruga, como rica alternativa para estabelecer comunicação com a sociedade hodierna; evidenciar as consequências teológicas da concepção de revelação e sua práxis. A dimensão do sofrimento e da cruz aponta que o silêncio divino, é consequência da surdez e resistências humanas no processo de acolhida da revelação. Ele cria para salvar e, ao salvar, revela-se. Os resultados esperados apontam a necessidade de um árduo e dedicado trabalho de retraduzir - com as categorias da linguagem moderna - a fé revelada de modo pleno em Jesus de Nazaré. No afã de mostrar que o embate não é o melhor caminho para a percepção de Deus, sabiamente o autor busca uma zona de contato entre aquilo que existe de melhor tanto na fé quanto na modernidade. A partir dessa percepção pedagógico-metodológica da necessidade de valorizar "o melhor com o melhor", isto é, aquilo que é o essencial de cada uma, a sua obra ressalta a concepção de revelação para a realização do homem.

Palavras-chave: Revelação divina. Torres Queiruga. Teologia da revelação. 